\title{
Case report: tolvaptan-associated creatine kinase elevation in two patients with autosomal dominant polycystic kidney disease (ADPKD)
}

\author{
I. Agraz-Pamplona ${ }^{1}$ (D) - M. Larrosa-Garcia ${ }^{2}$ - R. P. Bury-Macias ${ }^{1}$ • D. Serón-Micas ${ }^{1}$ • J. B. Montoro-Ronsano ${ }^{2}$
}

Received: 9 December 2019 / Accepted: 20 May 2020 / Published online: 8 June 2020

(C) The Author(s) 2020

Autosomal dominant polycystic kidney disease (ADPKD) is a genetic disorder that leads to an abnormal polycystin protein, which causes hypertension and cysts in different organs. The goal in ADPKD is to postpone kidney damage; however, there are no specific treatments [1].

Vasopressin antagonists decreased cAMP and cell proliferation in kidney epithelial cells and improved renal function in ADPKD-rodent models [2]. Tolvaptan (Jinarc®, Otsuka Pharmaceutical, Japan), an oral vasopressin-antagonist used for SIADH, slowed cyst development in ADPKD patients during TEMPO 3:4 and 4:4 clinical trials; adverse events (AE) were polydipsia, headache, polyuria, and fatigue [3-5]. It was approved for ADPKD in 2015 [6]; it is recommended to start treatment with $45 \mathrm{mg}$ in the morning and $15 \mathrm{mg}$ in the evening (45-0-15) and increase it according to tolerance.

\section{Case 1}

A 41-year-old man was diagnosed with familial ADPKD at the age of 34 . He had cysts in kidney and liver, and showed no symptoms other than hypertension. His kidney function was acceptable, $1.2 \mathrm{mg} / \mathrm{dL}$ mean creatinine plasma concentration (Cr). On 1 December 2018, his Cr was $1.66 \mathrm{mg} / \mathrm{dL}$, and there was an increase in number and size of the cysts; due to the rapidly progressive ADPKD (clearance decrease $>5 \mathrm{~mL} / \mathrm{min} /$ $1.73 \mathrm{~m}^{2} /$ year) tolvaptan was started. The $45-0-15$ dose of tolvaptan was well-tolerated, and the patient only reported

I. Agraz-Pamplona

iagraz@vhebron.net

1 Division of Nephrology, Vall d'Hebron University Hospital, Barcelona, Spain

2 Hospital Pharmacy, Vall d'Hebron Hospital Campus, Barcelona, Spain thirst (an expected AE). After 20 days of treatment, the recommended blood test to evaluate tolvaptan-associated hepatotoxicity [6] showed a dramatic increase of creatine kinase (CK) plasma concentration from $256 \mathrm{UI} / \mathrm{L}$ (before tolvaptan) to $585 \mathrm{UI} / \mathrm{L}$ (normal range 22-198 UI/L). Lactate dehydrogenase (LDH) concentration was $432 \mathrm{UI} / \mathrm{L}$ (normal values 208 $387 \mathrm{UI} / \mathrm{L}$ ), Cr did not vary, and the patient did not show clinical symptoms. The nephrologist did not find a cause for CK elevation, so it was decided to stop tolvaptan. Four weeks after, CK and LDH plasma levels recovered to basal level, and the patient reported feeling better than before.

\section{Case 2}

A 43-year-old man was diagnosed with familial ADPKD at the age of 34 . His kidneys were bigger than normal and contained numerous cysts; he had no liver cysts and normal laboratory tests with slightly high $\mathrm{Cr}(1.1 \mathrm{mg} / \mathrm{dL})$. Disease symptoms were controlled for 5 years with enalapril, amlodipine, and allopurinol. In December 2018, infinite bleeding renal cysts were detected, and Cr was $1.55 \mathrm{mg} / \mathrm{dL}$. Due to the ADPKD rapid progression, tolvaptan was initiated on 4 May 2019 at the regular dose, 45-0-15. After 17 doses of treatment, blood tests revealed a 5-6 fold increase of CK (from 154 to $854 \mathrm{UI} / \mathrm{mL}$ ) and a moderate increase in $\mathrm{LDH}$ (364 UI/L). Cr did not increase during this time, and the patient did not have symptoms. Tolvaptan was stopped, while other treatments continued, and CK and LDH (307UI/L) gradually recovered after 6 weeks.

Both patients suffered a dramatic CK elevation after receiving tolvaptan and neither showed symptoms. They had no history of CK elevation and reported not having taken any other drug, phytotherapy, or special diet and not having performed extreme exercise that could justify CK elevation [7]. The LDH increase was minor; however, it is usually high in 


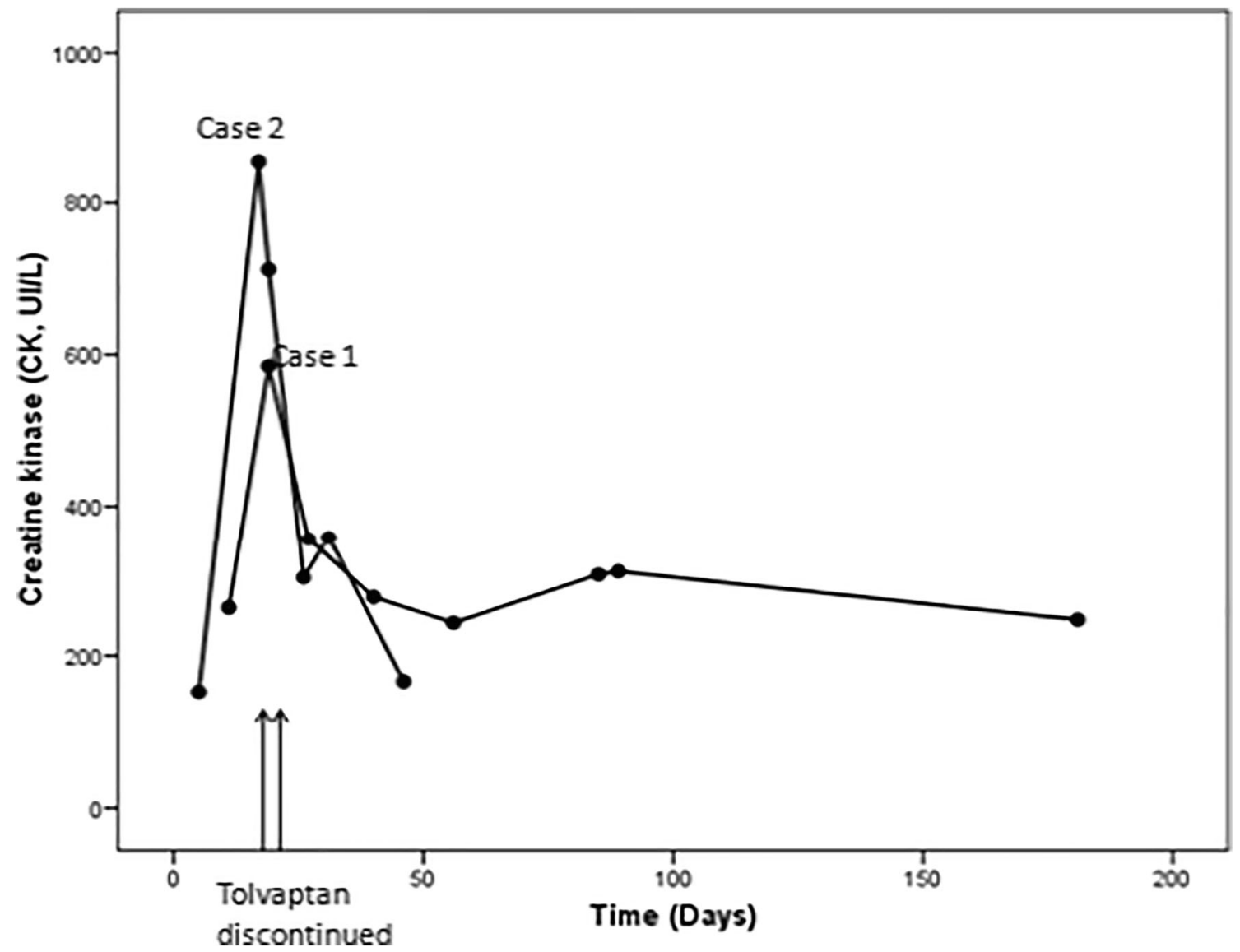

Fig. 1 Creatine kinase (CK) plasma concentration during and after tolvaptan treatment. Case 1 and Case 2 are shown. Lines indicate day of treatment discontinuation

ADPKD due to cyst breakage. In the absence of any other justification for CK elevation and since CK decreased after tolvaptan discontinuation, it is probable that tolvaptan caused CK elevation in both cases [8] (Fig. 1).

These are the first cases of tolvaptan-induced CK elevation reported. It is well-known that tolvaptan causes hepatotoxicity in ADPKD patients [9] but not in other patients [10]. Since CK elevation is caused by muscle damage [7], we hypothesize that tolvaptan might damage ADPKD patients' myocytes and hepatocytes by the same mechanism, probably related with intracellular cAMP reduction. Since CK elevation might be underestimated in ADPKD patients receiving tolvaptan, we suggest that CK should be monitored in these patients.

\section{Compliance with ethical standards}

Conflict of interest All authors have no conflict of interest to report.

Open Access This article is licensed under a Creative Commons Attribution 4.0 International License, which permits use, sharing, adaptation, distribution and reproduction in any medium or format, as long as you give appropriate credit to the original author(s) and the source, provide a link to the Creative Commons licence, and indicate if changes were made. The images or other third party material in this article are included in the article's Creative Commons licence, unless indicated otherwise in a credit line to the material. If material is not included in the article's Creative Commons licence and your intended use is not permitted by statutory regulation or exceeds the permitted use, you will need to obtain permission directly from the copyright holder. To view a copy of this licence, visit http://creativecommons.org/licenses/by/4.0/.

\section{References}

1. Chapman A, Devuyst O, Eckardt K, Gansevoort R, Harris T, Horie S, Kasiske BL, Odland D, Pei Y, Perrone RD, Pirson Y, Schrier RW, Torra R, Torres VE, Watnick T, Wheeler DC, Conference Participants (2015) Autosomal-dominant polycystic kidney disease (ADPKD): executive summary from a Kidney Disease: Improving Global Outcomes (KDIGO) Controversies Conference. Kidney Int 88(1):17-27

2. Chang M, Ong A (2012) Mechanism-based therapeutics for autosomal dominant polycystic kidney disease: recent progress and future prospects. Nephron Clin Pract 120(1):c25-c35

3. Devuyst O, Chapman A, Gansevoort R et al (2016) Urine Osmolality, Response to tolvaptan, and outcome in autosomal dominant polycystic kidney disease: results from the TEMPO 3:4 Trial. J Am Soc Nephrol 28:1592-1602

4. Torres V, Chapman A, Devuyst O, Gansevoort R, Grantham J, Higashihara E, Perrone RD, Krasa HB, Ouyang J, Czerwiec FS, TEMPO 3:4 Trial Investigators (2012) Tolvaptan in patients with 
autosomal dominant polycystic kidney disease. N Engl J Med 367(25):2407-2418

5. Torres VE, Meijer E, Bae KT, Chapman AB, Devuyst O, Gansevoort RT, Grantham JJ, Higashihara E, Perrone RD, Krasa HB, Ouyang JJ, Czerwiec FS (2011) Rationale and design of the TEMPO (Tolvaptan Efficacy and Safety in Management of Autosomal Dominant Polycystic Kidney Disease and its Outcomes) 3-4 Study. Am J Kidney Dis 57:692-699

6. Jinarc $®$ (tolvaptan). Summary of product characteristics. European Agency of Medicines. https://www.ema.europa.eu/en/documents/ product-information/jinarc-epar-product-information en.pdf. Accesed Apr 16 ${ }^{\text {th }}, 2019$.

7. Moghadam-Kia S, Oddis C, Aggarwal R (2016) Approach to asymptomatic creatine kinase elevation. Cleve Clin J Med 83(1): $37-42$
8. Naranjo C, Busto U, Sellers E et al (1981) A method for estimating the probability of adverse drug reactions. Clin Pharmacol Ther 30: 239-245

9. Woodhead J, Brock W, Roth S, Shoaf S, Brouwer K, Church R, Grammatopoulos TN, Stiles L, Siler SQ, Howell BA, Mosedale M, Watkins PB, Shoda LK (2016) Application of a mechanistic model to evaluate putative mechanisms of tolvaptan drug-induced liver injury and identify patient susceptibility factors. Toxicol Sci 155(1):61-74

10. Watkins P, Lewis J, Kaplowitz N et al (2015) Clinical pattern of tolvaptan-associated liver injury in subjects with autosomal dominant polycystic kidney disease: analysis of clinical trials database. Drug Saf 38:1103-1113

Publisher's note Springer Nature remains neutral with regard to jurisdictional claims in published maps and institutional affiliations. 